\author{
Людмила Садко
}

Брестский государственный университет

\title{
Расширение границ эстетического в лирике Алеся Навроцкого
}

Необходимо констатировать, что 50-60-е годы XX века для белорусской литературы были весьма неоднозначными. С одной стороны, данный период ознаменован формированием «оттепельной» ситуации, некоторой демократизацией общественной жизни, что позволило заявить о себе ряду деятелей искусства и литературы Беларуси. С другой стороны, сохранение строгой регламентированности творчества, принципы социализма, сужение сферы функционирования белорусского языка и национальной культуры не позволяют говорить о формировании аутентичной и свободной культурной ситуации. Предпочтение отдавалось темам коммунистических свершений, строительства светлого будущего. Из дозволенных партийной цензурой тем преобладали темы осмысления военного прошлого, изображения социалистической реальности. Однако в данных условиях формируется целое движение писателей «филологического поколения», в творчестве которых доминируют интенсивные поиски гуманистических идеалов, ожидание перемен, неприятие демагогии, партократии, фальши. Приход в литературу таких поэтов и прозаиков, как Рыгор Бородулин, Анатоль Вертинский, Генадь Буравкин, Владислав Недведский, Нил Гилевич, Владимир Короткевич, Пятрусь Макаль, Борис Саченко, ознаменовал в своём роде оппозиционное движение против официальной художественной системы, за которой закрепилось название «искусство соцреализма». Поэзия «филологического поколения» вернула в литературу традиционные, вечные темы - поэтизацию родного края и его истории, рефлексию художника, обращение к мифопоэтической стихии. 
Всё это на фоне пафосных тем комсомола, ленинианы и прочих идеологических штампов стало своего рода важным идейно-художественным открытием. В этой связи очень точно характеризует ситуацию В. В. Гниломёдов, в форме парадокса отмечая, что настоящими новаторами нередко оказываются не экспериментаторы - впрочем, слово это совсем не позорное, - а "традиционалистье". В том же ключе высказывается и теоретик и практик авангардизма Х. Хайссенбюттель о существовании странного стереотипа, ито "модерн" и "традииии" себя взаимно исключают (merkwürdiges Klischeе, nach welchem "Moderne" und "Tradition" sich gegenseitig ausschließen)2. Возвращенные в поэтический обиход белорусской литературы подчёркнутый лиризм, богатое эмоционально-стилевое разнообразие и новаторская инструментовка текста в поэзии шестидесятников сформировали предпосылки для дальнейшего реформирования белорусского стиха.

Подобный «идеологический» критицизм, свойственный творчеству белорусских писателей-шестидесятников, соответствует общеевропейским и мировым социокультурным тенденциям послевоенного периода. Литература и в целом культура 50-60-х гг. ХХ в. формируются «на обломках иллюзий», пронизаны мотивами разочарования, достаточно вспомнить знаменитый тезис Т. Адорно о культуре «после Аушвица».

Известный белорусский литературовед Н. Арочко, размышляя о своеобразии творчества «филологического поколения», отмечает: Подняться на новый этап и удержаться можно было через бескомпромиссное самоочищение, человеческое и творческое. Прилив сил добавляло решительное отречение от всего недостойного и непростительного не только в других, но и в себе. Точнее - через отречение и явлений общественного порядка ${ }^{3}$. Так, в СССР после Сталина, в Германии после Гитлера тоталитарное прошлое, породившее не только социальные проблемы, но и чувство эстетической катастрофы, привело к параллельному возникновению в таких различных национальных литературах схожего явления - эстетики и поэтики конкретной поэзии.

Элементы лингвистического критицизма, деструкция привычных представлений о канонических заповедях письма, новаторские и оригинальные находки в области рифмовки, пробуждения внутренних созвучий слова, возможностей алхимии звукописи в творчестве П. Макаля,

1 У. В. Гніламёдай, Традыцыі $і$ наватарства, Мінск 1972, с. 76.

2 H. Heissenbüttel, Nachwort // Ernst Jandl, Laut und Luise, Stuttgart 2000, s. 156.

3 М. М. Арочка, Вяршаліна паэзіi, «Полымя» 1995, № 11, с. 235. 
Р. Бородулина; обращение к возможностям гротеска и абсурдизации, к принципам свободной поэтики в произведениях А. Навроцкого, выразительно проявившие себя в наследии этих поэтов 1960-1970-е гг., дают основания проводить параллели с творческими поисками европейского и мирового неоавангарда.

Напряжённые поиски собственного пути, отказ от эстетики социалистического реализма, обновление и реформирование поэтического языка особенно выразительно проявили себя в творчестве Алеся Навроцкого (1937-2012), белорусского поэта, прозаика, диссидента. Стихи сборников А. Навроцкого «Неба ўсміхаецца маланкаю» (1962), «Гарачы снег» (1968) прозвучали особенно эпатажно, новаторски, вызвав целую серию публикаций на страницах периодики. Свои «за» и «против» высказали Н. Арочко, Г. Берёзкин, В. Короткевич, М. Лужанин, Г. Юрченко, И. Шпаковский, склоняясь к мнению об «оригинальности» и «крайностях» творческой манеры, особенном взгляде на мир.

Вообще, протестный характер авангардизма середины XX века во многом выказывает себя именно в радикальном недоверии общепринятому языку, обслуживающему порочную реальность с вросшим в неё тоталитаризмом. Лингвистический критицизм проявил себя и в поэзии А. Навроцкого, прозвучавшей в 60-е гг. ХХ в. вызывающе смело и свежо. Подлинно трагический гротеск звучит во многих текстах поэта, касаясь и социалистической действительности, и духовного нивелирования человека внутри тоталитарной системы, и рефлексии о современном состоянии языка и мышления.

Необходимо отметить маргинальные настроения поэзии сборников «Неба ўсміхаецца маланкаю» и «Гарачы снег» А. Навроцкого в контексте общепринятой официальной литературы этого периода. Обращение к элементам абсурдистской поэтики, использование нарочито сниженной интонации, стремление воспроизвести образ языковой и ситуативной повседневности, лишённой какой бы то ни было героики, пафосности и показной лиризации, лежат в основе стратегии письма А. Навроцкого. Как отмечает А. Сёмуха, натуралистичность, гиперболизированные аллегории и необычные, часто болезненно-нервные образы его первых, ещё художественно не обработанных стихов, освежали поэтическую атмосферу того времени ${ }^{4}$.

4 А. Сёмуха, «Адзінока плячециа мая льюня...». Твориы лёс Алеся Наўрочкага, "Роднае слова" 1995, № 3, с. 8. 
Так, традиционная тема одиночества, имеющая в литературе долгую историю осмысления, становится предметом особенного разговора и в стихотворении «Адзінота» ${ }^{5}$. В этом произведении А. Навроцкий проявляет себя как мастер своеобразного комического, как поэт с «двойным зрением», позволяющим одновременно видеть разные стороны события: «кажимость» и сущность. Каждая строфа стихотворения, открываясь классическим, нарочито привычным зачином двух первых строк, в завершающей фразе получает неожиданную развязку, резко диссонирующую с представлениями о традиционной поэтике:
Як быць? Куды пайсці сягоння?
На прызбу сяду пад акном,
а мухі будуць
бзымкаць сонна
за павуцінным мутным шклом.
Я камень шыбану у проса, што вераб'ямі зарасло.
Па недакурках папяросных
пайду сцяжынай за сяло.

Тотальная неустроенность героя, его одиночество - порождение неладно организованного мира, тотально враждебного человеку. Принципиальная открытость слога А. Навроцкого прозе, изнанке жизни демонстрирует табуированные подцензурной литературой пласты действительности и быта. Самоценность разговорной речи, примитивистская, несколько гротескная поэтика проявляет себя и в стихотворении «Вясновыя думкі» ${ }^{6}$.

Текст представляет собой цикл из шести двустиший, только первое из которых соответствует собственно лирическому канону. Следующие двустишия служат антитезой, по-особенному развивающей заявленную в заголовке тему весенних раздумий. Стихотворение будто подтрунивает над обманутыми читательскими ожиданиями:

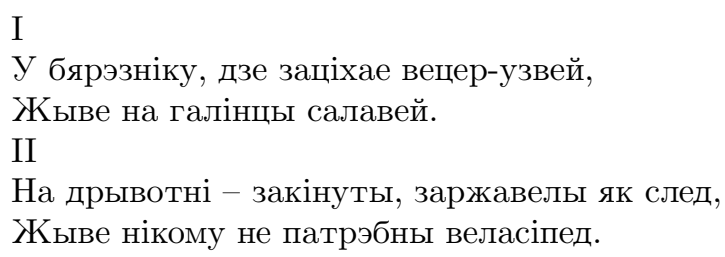

\footnotetext{
5 А. Наўроцкі, Гарачьл снег, Мінск 1968, с. 35.

6 А. Наўроцкі, Неба ўсміхаециа маланкаю, Мінск 1962, с. 32.
} 
III

У суседкі на твары жыве нос кірпаты,

Я за ім назіраю з акна сваёй хаты.

IV

I у душы маёй, мне назло,

Каханне да гэтага носу ажыло.

$\mathrm{V}$

Эх, вясна, ты, вясна, адна прыгажосць!

Усе элементы кахання ёсць.

$\mathrm{VI}$

Калі так, на веласіпедзе да салаўя

Паедзем - мая суседка і я.

Герой подобных стихов одновременно соединяет в себе черты бунтаря и шута, высказывающего правдивые замечания, которые никто не воспринимает всерьёз, что добавляет образу трагичность, как это свойственно «чердачным» героям Гоголя и Достоевского. Образ маленького человека, деформированный системой до уровня ничтожного, находит выражение в поэзии А. Навроцкого. Даже тема любви представлена в произведениях поэта зачастую антипоэтично, из подручных средств неустроенного быта, как в стихотворении «Успамін» ${ }^{7}$ :

Цыбулі вязкі, печ, паўзмроку цень.

Пячэ жывот мой соладка чарэнь,

Пад галавою - нейкія бахілы.

Марозны вецер надрывае жылы,

Ніяк не надарваў за цэлы дзень.

Ён ные у коміне і барабаніць юшкай...

Прыціхнуў я, накрыўшыся дзяружкай.

Именно такой «низовой», неприбранный мир обыденности становится декорациями для игры фантазий влюблённого о своей избраннице. Несмотря на шаржированность ситуации, далёкой от романтического антуража, чувства героя глубоки, полны нежности и свежести настоящего чувства.

В палитре поэта встречаются и стилизации под фольклорные стихи-нескладушки, распространённые в детском творчестве. Немного наивный, примитивистский взгляд на действительность, оформленный как миниатюра, зарисовка с натуры, представлен в стихотворении «Абледзяніў мароз»8:

\footnotetext{
7 А. Наўроцкі, Гарачы снег, с. 20.

8 Tамсама, c. 24.
} 
Абледзяніу мароз заснежаныя кусты,

Вылятае $з$ рота белай ватай.

Нічога не трэба мне - толькі ты

I кажух з каўняром паднятым.

Предельно конкретизированно, с большим количеством деталей быта берется А. Навроцкий и за описание советского образа жизни. Но стихи цикла «Элегіi» далеки от традиций «сурового реализма» эпохи, они в большинстве своём основаны на приёмах абсурдизации, демонстрируют несоответствие причинно-следственных связей. Несмотря на это, «Элегіi» напоминают отчасти этнографические очерки, отчасти дневниковые записки человека, живущего под гнётом выморочного советского тоталитаризма:

Я страшэнна мух не люблю.

Перад тым, як легчы спаць, я іх лаўлю

I запіхваю ў нос: усё роўна яны туда залазяць,

Дык я рашыў іх сам запіхваць.

Падымаюся, калі сонца над галавой,

I, каб памыцца халоднай вадой,

Цёплую ваду стаўлю у халодны склеп:

Хай астывае ${ }^{9}$.

Подобная спутанность сознания, нелогичность мышления, срывающегося к абсурдным умозаключениям, порождены косностью и жестокостью системы, в которой, по словам поэта, «трэба ж неяк выкручвацца»10, где человек изначально не свободен в своих желаниях и поступках, вынужден кривить душой и приспосабливаться. О масштабности происходящего говорит сам лирический герой, признаваясь, «вось так і жыву ўсё жыццё»11, а «кваканне жаб заглушае спеў салаўя» ${ }^{12}$.

О последнем тексте необходимо добавить, что это блестящий пример национального моностиха, или удетерона, минимального по размеру текста, обладающего особым выразительным потенциалом, мощной художественной содержательностью. Философско-содержательная интонация этого моностиха А. Навроцкого тяготеет к явлению паремии, текст имеет интенцию к «разворачиванию» этой текстуаль-

\footnotetext{
9 А. Наўроцкі, Неба ўсміхаециа маланкаю, с. 53.

10 Тамсама, с. 53.

11 Тамсама, с. 53.

12 Тамсама, с. 56.
} 
но-поэтической единицы до размышлений о тотальной несправедливости мироустройства. Надо отметить, что образцы удетерона как в отечественной, так и в русскоязычной литературе середины XX века по преимуществу нашли воплощение в неподцензурной литературе андеграунда, диссидентов и писателей-эмигрантов за счёт подчёркнутого экспериментального характера моностиха.

Таким образом, исследование границ языка, лингвистические конвертации, богатство интонации, характерные для поэзии А. Навроцкого, ведут к обновлению и трансформации конвенциального языка художественной литературы, демонстрируют стремление расширить возможности функционирования лингвистических единиц, усилить выразительные возможности поэтической речи, что приводят к выходу за пределы функционально-семантических закономерностей, в пространство поэтического эксперимента. В произведениях А. Навроцкого заявленные языковые конвертации - эксперименты со звуковой инструментовкой, игровые приёмы, мастерство в выявлении внутренних созвучий слова, обыгрывание ситуации лингвистической и ситуативной повседневности, абсурдизация и гротеск - конструируют смысл текста наравне с его семантикой, усиливают экспрессивность произведения и формируют оригинальность индивидуально-авторского стиля А. Навроцкого.

\title{
Л I T A P А T У P A
}

Арочка М. М., Вяршаліна паэзіі, «Полымя» 1995, № 11.

Гніламёдаў У. В., Традыцыіi і наватарства, Мінск 1972.

Наўроцкі А., Гарачьъ снег, Мінск 1968.

Наўроцкі А., Неба ўсміхаециа маланкаю, Мінск 1962.

Сёмуха А., «Адзінока плячециа мая льюня...». Творчы лёс Алеся Найрочкага, "Роднае слова" 1995, № 3.

Heissenbüttel H., Nachwort // Ernst Jandl, Laut und Luise, Stuttgart 2000.

\author{
S T R E S Z C Z E N I
}

\section{ROZSZERZENIE GRANIC ESTETYKI W LIRYCE ALESIA NAWROCKIEGO}

$\mathrm{W}$ artykule przedstawiono wyniki badania awangardowych i neoawangardowych tendencji w tekstach białoruskiego poety Alesia Nawrockiego. Omówiono 
transformację języka konwencjonalnego literatury pięknej, techniki wzmacniania intelektualizacji poezji i zastosowanie jakościowo nowych słów. Często początek utworów A. Nawrockiego stanowią elementy gry, eksperymenty z dźwiękową realizacją tekstu poetyckiego, wzmocnienie rytmiczności wiersza wolnego i akcentowanego, obecność nowoczesnych form rytmicznych, wewnętrzna harmonia słów, dominacja groteski i absurdu.

Słowa kluczowe: „pokolenie filologiczne”, nowatorstwo, obraz małego człowieka, eksperymentalny charakter wiersza.

\section{S U M M A R Y}

\section{THE EXTENSION OF ESTHETIC LIMITS IN ALES NAVROTSKY'S LYRIC POETRY}

In the article the results of the analysis of the avant-garde and neo avant-garde tendencies in the lyric poetry of Belarusian poet Ales Navrotsky are presented. The transformation of conventional language in literature, techniques of increasing intellectual significance of poetry, and developing wording are also discussed. Very often Navrotsky's poetry is based on playful approaches, experiments with sounding of poetic texts, additional attention to the rhythmic capabilities of free and accentual verses, nontraditional rhythm formats, internal harmony of words, and attraction to grotesque and absurd.

Key words: "philological generation", innovation, picture of a small man, experimental character of verse. 